\title{
Assessment of progression of asbestosis in the sheep model by bronchoalveolar lavage and pulmonary function tests
}

\author{
R BEGIN, M ROLA-PLESZCZYNSKI, S MASSE, D NADEAU, G DRAPEAU, with the \\ assistance of S Péloquin, Y Côté, S Gouin
}

\begin{abstract}
From l'Unité de Recherche Pulmonaire, Centre Hospitalier Universitaire de Sherbrooke, Sherbrooke, Québec, Canada
\end{abstract}

ABSTRACT To study the relationship between the results of bronchoalveolar lavage and pulmonary function tests during induction and progression of asbestosis, three groups of six sheep were exposed repeatedly by intratracheal injection to either saline (controls), low doses of Canadian chrysotile UICC asbestos (cumulative exposure $328 \mathrm{mg}$ ) (low-dose group), or high doses of the same fibres (cumulative dose $2282 \mathrm{mg}$ ) (high-dose group) until there was clear evidence of alveolitis from the lung biopsy specimens of all sheep of the high-dose group. During the course of this induction and for the following eight months lung biopsies, bronchoalveolar lavage and pulmonary function tests were performed at two-month intervals. At the time of initial alveolitis in the high-dose group there was no significant change in the cellularity of the bronchoalveolar lavage fluid, but static lung compliance $\left(\mathrm{C}_{\mathrm{st}}\right)$, vital capacity $(\mathrm{VC})$, arterial oxygen tension $\left(\mathrm{PaO}_{2}\right)$, and diffusion capacity $(\mathrm{DL} / \mathrm{VA})$ were significantly lower than in the other groups. In the following months, as the alveolitis evolved into a fibrosing process, macrophages and neutrophils from the bronchoalveolar lavage fluid increased significantly and pulmonary function deteriorated. Proteins and enzymes in the bronchoalveolar lavage fluid also increased significantly in the high-dose group. These data show that in the sheep model of asbestosis simple tests of pulmonary function correlate well with histological changes and changes in the bronchoalveolar lavage fluid in the course of the disease and can be used to assess progression of asbestosis.

Current theories of the pathogenesis of interstitial pulmonary fibrosis suggest that fibrosis of the lung is the end-stage result of a chronic inflammatory process of the alveoli and interstitium, which can be evaluated and staged either by histopathological criteria on the basis of lung biopsy material or by analysis of bronchoalveolar lavage fluid. ${ }^{2}$ Because it is a safe and easily repeatable procedure the latter has already been used extensively to follow the progress of the alveolitis and its response to treatment in many treatable interstitial pulmonary diseases. ${ }^{1-6}$

Because asbestosis is at present a non-treatable disease, the clinician has little justification for repeating lung biopsy or bronchoalveolar lavage. $\mathrm{He}$ must rely on pulmonary function tests and chest

\footnotetext{
Address for reprint requests: Dr $\mathbf{R}$ Bégin, Unité de Recherche
} Pulmonaire, CHUS, Sherbrooke, Québec, Canada J1H 5N4.

Accepted 8 February 1983 radiography to assess the progress of asbestosis even though the value of these tests in the monitoring of the activity of other interstitial pulmonary diseases has been questioned..$^{7-11}$

The aim of the present study was to evaluate the intensity of the alveolitis of asbestosis in the course of induction and progression of the disease in the sheep model and to relate the stage of the alveolitis as assessed by bronchoalveolar lavage to pulmonary function as assessed by the tests commonly used for the follow-up of patients with the disease. It was hoped that the study would identify pulmonary function test correlates of the activity of alveolitis in asbestosis which would be of practical value in assessing the progress and prognosis of the disease.

\section{Methods}

EXPERIMENTAL DESIGN

Eighteen male sheep weighing $25-50 \mathrm{~kg}$ (mean 
$39 \cdot 5, \mathrm{SD} \pm 10 \mathrm{~kg}$ ) at the beginning of the study were selected for this investigation. They were prepared and accustomed to the pulmonary techniques as previously reported..$^{1213}$ The flock was divided into three groups of six sheep, which were subjected to monthly exposures during the first six months and to weekly exposures during the next six months. Each time the control sheep were given a 50-ml intratracheal injection of saline. The low-exposure group received a cumulative dose of $328 \mathrm{mg}$ of UICC Canadian chrysotile fibres in saline and the highexposure group a cumulative dose of $2282 \mathrm{mg}$ of the fibres in saline. UICC Canadian chrysotile B asbestos fibres were kindly provided by Dr V Timbrell of the Medical Research Council, Pneumoconiosis Unit, Penarth, and Mr REG Rendall of the Pneumoconiosis Research Unit, Johannesburg. These asbestos fibres were relatively uniform and well characterised, ${ }^{14} 92 \%$ being less than $0.25 \mu \mathrm{m}$ in diameter and $20 \mu \mathrm{m}$ in length. Exposure was stopped after the 12th month of intratracheal injections, which led to the development of an initial alveolitis in all sheep in the high-exposure group. Every two months all sheep were studied by transbronchial lung biopsy, pulmonary function tests, and bronchoalveolar lavage, as previously reported. ${ }^{12}$ At the 12 th and 20th months one sheep in each group was killed for detailed histopathological study.

\section{TRANSBRONCHIAL LUNG BIOPSY AND}

HISTOPATHOLOGY

Under local anaesthesia of the airways transbronchial lung biopsy specimens were obtained by a technique already described ${ }^{12}$ from randomly selected areas of the lung. The lung samples were immediately placed in $10 \%$ buffered formalin solution and processed in the clinical pathology laboratory of our institution in the same way as human lung biopsy specimens. Iron and Masson stains were performed on selected biopsy specimens. This procedure was well tolerated by all animals and did not cause complications other than limited bleeding in the airway. The lungs of the animals that were killed were removed from the chest cavity and one lung was immediately fixed at full inflation with the liquid formalin intrabronchial infusion technique. ${ }^{15}$ The other lung was fixed with formalin vapour at full inflation. Lung samples taken from upper, middle, and lower lung zones of the former were also processed like human lung biopsy specimens.

\section{PULMONARY FUNCTION TESTS}

The methods used in the assessment of the sheep have been published. ${ }^{12}$ Briefly, transpulmonary pressure was monitored with a naso-oesophageal 7-ml balloon catheter and an airway catheter con- nected to a Hewlett-Packard 270 differential transducer. Gas flow at the airway opening was measured by connecting the cuffed endotracheal tube to a Fleisch No 2 pneumotachograph attached to a flowmeter integrator recorder system. Functional residual capacity (FRC) was determined by the helium rebreathing method, and this was followed by syringe lung inflation to a transpulmonary pressure of $35 \pm 5 \mathrm{~cm} \mathrm{H} O$, which we called total lung capacity (TLC), and by lung deflation to a transpulmonary pressure of $-35 \pm 5 \mathrm{~cm} \mathrm{H}_{2} \mathrm{O}$, termed here residual volume (RV). These measurements were obtained after a three-inspiratory capacity (IC) constant-volume history. The following lung volumes were determined: TLC, RV, FRC, IC, vital capacity (VC), and expiratory reserve volume (ERV). Lung volume data were calculated at BTPS (the rectal temperature of sheep being $39^{\circ} \pm 0 \cdot 2^{\circ} \mathrm{C}$ ). Pulmonary compliance $\left(C_{1}\right)$ and resistance $\left(R_{1}\right)$ were measured by feeding the output of the transpulmonary pressure transducer, flowmeter, and integrator to a recorder and oscilloscope system. ${ }^{12}$ Checked for accuracy under static and dynamic conditions, the system was found to be linear up to $4 \mathrm{~Hz}$. The static expiratory lung compliance $\left(\mathrm{C}_{\mathrm{st}}\right)$ was determined by multiple-step syringe deflation between TLC and FRC. The lung resistance $\left(R_{1}\right)$ was measured during tidal volume by the electrical subtraction technique. Diffusion capacity (transfer factor-DLCO) was obtained by a passive rebreathing method using a gas mixture of $10 \%$ helium, $0.30 \%$ carbon monoxide, and $21 \%$ oxygen in nitrogen; a Collins catherometer; and a Beckman infrared carbon monoxide analyser, which necessitated the use of three $500-\mathrm{ml}$ gas samples as suggested by Marshall. ${ }^{16}$ For this test the intubated conscious sheep was passively ventilated with a $2 \cdot 5$-litre syringe at a rate of 30 breaths a minute and with a 1 -litre tidal volume. Pulmonary gas exchange data were obtained by standard techniques while the animal was breathing room air and resting quietly. These tests were done while the animals were awake. The intra-individual variability of the measurements has been reported and is similar to that found in man. ${ }^{12}$

BRONCHOALVEOLAR LAVAGE FLUID ANALYSIS Most of the techniques used in bronchoalveolar lavage procedures and analyses have been previously described..$^{12}{ }^{17}$ Briefly, lung lavage was performed by slow infusion of three $50-\mathrm{ml} 39^{\circ} \mathrm{C}$ aliquots of phosphate-buffered saline through a 50-ml Luerlock syringe attached to the work channel of the bronchoscope and by gentle syringe aspiration of the effluent. The effluent was passed through four layers of cheesecloth to remove mucus and the cells were 
pelleted by centrifugation. Cells were counted in a haemocytometer and cell viability, as determined by the trypan blue exclusion technique, averaged $90 \%$. Cytocentrifuge smears served to identify the cell population recovered with the use of WrightGiemsa and naphthyl acetate esterase stains. ${ }^{17}{ }^{18}$ In the supernatant total proteins were measured by the method of Pesce and Strande ${ }^{19}$ and after concentration 100 times with Amicon B-15 filters electrophoresis on cellulose acetate permitted the concentrations of albumin and gammaglobulin to be determined. The levels of $\beta$-glucuronidase (B-glu), a lysosomal enzyme, and lactate dehydrogenase, a cytoplasmic enzyme, were determined with a Beckman Trace III clinical chemistry system associated with a model 35 spectrophotometer and expressed per millilitre of bronchoalveolar lavage fluid. All values of humoral components of bronchoalveolar lavage fluid were also analysed in terms of ratio to the albumin content of the supernatant of the fluid. ${ }^{20}$

\section{ANALYSIS OF THE DATA}

In the presentation of the results mean values of the data from each group of sheep are followed by the standard error (SE) as an index of dispersion. The data were evaluated by two-factor analysis of variance for experiments having repeated measurements on the same subjects. When a significant effect was detected, a Kruscal-Wallis test was used to determine which group means were significantly different. The Pearson correlation procedure was used to relate the results of pulmonary function tests and bronchoalveolar lavage data. The level of significance adopted was $\mathrm{p}<0.05$.

\section{Results}

\section{LUNG HISTOPATHOLOGY}

The yield of lung biopsy specimens was similar to that of our previous study and the histopathological features of the control material remained normal (fig 1, panel $a$ ). In the sheep exposed to low-dose asbestos an occasional mild increase in cellularity was noted in a few biopsy samples at different months, but in neither transbronchial nor necropsy lung biopsy specimens could we see definite changes in the microscopic appearances of the low-exposure group (fig 1, panel $b$ ). In the high-exposure sheep from month six to month 12 a macrophagic peribronchiolar alveolitis was seen with increasing frequency (fig 1, panel $c$ ), and at month 12 all sheep of the high-exposure group had definite lesions (fig 1, panel $d$ ). In the following months increased cellularity was noted in the biopsy specimens and interstitial fibrosis was also observed (fig 1, panels $e$ and f).
BRONCHOALVEOLAR LAVAGE ANALYSIS

The results of the cellular analysis of the bronchoalveolar lavage fluid are presented in figure 2. From these data it is clear that control and low-exposure groups could not be differentiated. The highexposure sheep, however, started to differ from the other groups at month eight with a significant increase in lactate dehydrogenase activity and at month 10 with increases in total proteins, albumin, and gammaglobulins in the bronchoalveolar lavage fluid. These changes in the high-exposure group persisted beyond month 12 without significant changes in the cellularity of the fluid. In the following months, however, with increasing differences between high-exposure sheep and the other sheep in the results of analysis of the bronchoalveolar lavage fluid supernatant, significant increases in the total cells, macrophages, and neutrophils in the fluid were observed. These changes in the high-exposure group persisted throughout the study.

\section{PULMONARY FUNCTION TESTS}

The static properties of the lung are presented in figure 3 . In controls the lung volumes, minute ventilation, tidal volume, and DLCo increased significantly with time and these increases paralleled the gain in body weight from an average of $39.5 \mathrm{~kg}$ at month 0 to $58 \mathrm{~kg}$ at month 20 . During the entire study FRC and RV did not differ between groups. $\mathrm{C}_{\mathrm{st}}$, however, was significantly lower in the high-exposure group at month 6 and this difference persisted. Significant changes in VC appeared at month 12 and in TLC at month 16 in the high-exposure group and these changes persisted. Furthermore, the low-exposure group started to differ from controls at month 16 in terms of $\mathrm{C}_{\mathrm{st}}, \mathrm{TLC}$, and VC. In figure 3 we also present the time course of gas exchange parameters. Here control and low-exposure groups did not differ. From month 8 these parameters were significantly different in the high-exposure group. As the disease progressed histologically they showed gradual deterioration. The hypoxia, tachypnoea, and diffusion impairment of the high-exposure group significantly worsened from month 12 to month 20 $(\mathrm{p}<0.01)$.

\section{RELATIONSHIP BETWEEN RESULTS OF \\ BRONCHOALVEOLAR LAVAGE FLUID ANALYSIS AND PULMONARY FUNCTION}

Because of the steady gain in body weight of our sheep and the related normal changes in some of the results of pulmonary function tests, we discarded the aging effect in our analysis by expressing pulmonary function values in the high-exposure group as percentages of values in control sheep that had a similar steady weight gain. In the table we present selected 



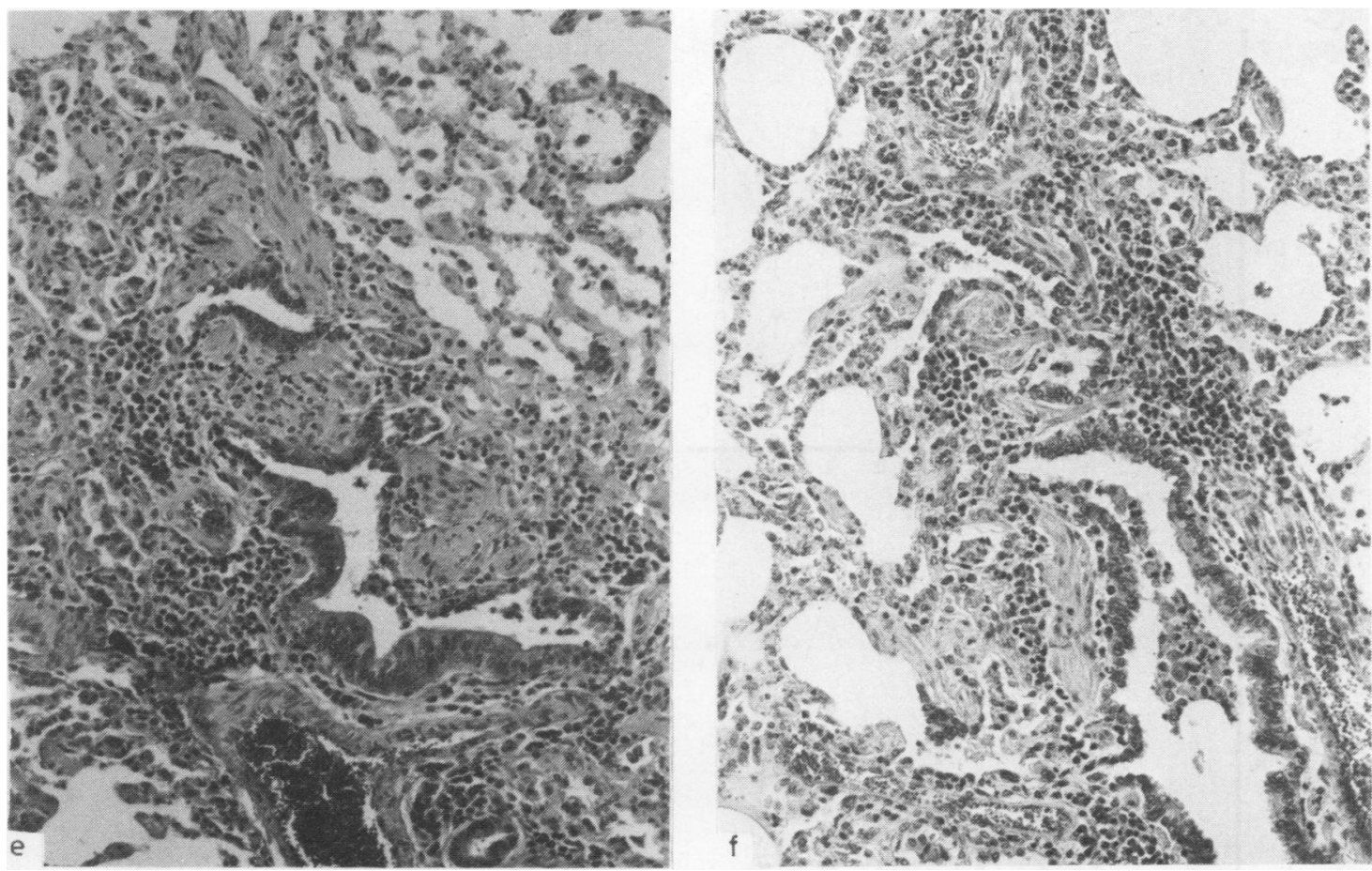

Fig 1 Panels (a)-(c) are photomicrographs of postmortem lung samples formalin fixed at full inflation (haematoxylin and eosin $\times 105$ ). Panel (a) is from a sheep in the control group at month 20. The alveoli, interstitium, and peribronchiolar tissues are normal. Panel (b) is from a sheep in the low-dose group at month 20. The alveoli, interstitium, and peribronchiolar tissues are normal. Panel (c) is from a sheep in the high-dose group at month 12. The interstitium and alveolar walls in the surroundings of peripheral airways are in filtrated by a predominantly macrophagic process. Panel (d) is a low-power photomicrograph obtained post mortem from the same sheep as panel c, and shows the peribronchiolar process and relatively normal lung tissue away from the bronchioles (haematoxylin and eosin; $\times 42$ ). Panel $(e)$ is a photomicrograph of a transbronchial lung biopsy specimen in a high-dose sheep at month 20. It shows the peribronchiolar macrophagic alveolitis, as well as some spindle cell proliferation suggestive of a fibroblastic proliferation (haematoxylin and eosin, $\times 105)$. Panel $(f)$ is a photomicrograph of a postmortem lung sample formalin foxed at full inflation from a sheep of the high-dose group at month 20 . The peribronchiolar process is similar to that seen in panel (e), with a clearer view of the fibroblastic proliferation in the peribronchiolar tissue (haematoxylin and eosin, $\times 105$ ).

Correlation coefficients $\dagger$ ( $r$ value) of selected pulmonary function tests $\ddagger$ with data from the analysis of bronchoalveolar lavage fuid

\begin{tabular}{|c|c|c|c|c|c|c|}
\hline & $C_{s t}$ & $T L C$ & $V C$ & $D L / V A$ & $\mathrm{PaO}_{2}$ & $\mathrm{PA}-\mathrm{aO}_{2}$ \\
\hline $\begin{array}{l}\text { Total bronchoalveolar lavage fluid cells } \$ \\
\text { Macrophages } \S \\
\text { Neutrophils } \\
\text { Total protein } \\
\text { Albumin } \\
\text { Gammaglobulin }\end{array}$ & $\begin{array}{l}0 \cdot 79^{* *} \\
0 \cdot 82^{* *} \\
0 \cdot 77^{* *} \\
0 \cdot 78^{* *} \\
0 \cdot 82^{* *} \\
0 \cdot 76^{* *}\end{array}$ & $\begin{array}{l}0 \cdot 84^{*} \\
0 \cdot 90^{*} \\
0 \cdot 80^{* *} \\
0 \cdot 86^{*} \\
0 \cdot 80^{* *} \\
0 \cdot 90^{*}\end{array}$ & $\begin{array}{l}0 \cdot 90^{*} \\
0 \cdot 93^{*} \\
0 \cdot 85^{*} \\
0 \cdot 85^{*} \\
0 \cdot 81^{* *} \\
0 \cdot 89^{*}\end{array}$ & $\begin{array}{l}0.81^{*} \\
0 \cdot 84^{*} \\
0 \cdot 81^{*} \\
0 \cdot 89^{*} \\
0 \cdot 81^{*} \\
0.92^{*}\end{array}$ & $\begin{array}{l}0 \cdot 85^{*} \\
0 \cdot 86^{*} \\
0 \cdot 84^{*} \\
0 \cdot 89^{*} \\
0.84^{*} \\
0 \cdot 92^{*}\end{array}$ & $\begin{array}{l}0.82^{* *} \\
0.70^{* * *} \\
0.80^{* *} \\
0.94^{*} \\
0.81^{* *} \\
0.91^{*}\end{array}$ \\
\hline
\end{tabular}

tCorrelations according to Pearson procedure relating changes in an index of pulmonary function with results of bronchoalveolar lavage fluid analysis at each point of measurement during the 20 months of the study.

$\ddagger$ Pulmonary function results converted to percentages of values in age-matched controls.

$\S$ Expressed as cells per $\mathrm{ml}$ of bronchoalveolar lavage fluid.

BAL - bronchoalveolar lavage; $C_{\mathrm{st}}$ - static lung compliance; TLC-total lung capacity; VC—vital capacity; DU/VA-diffusion capacity per unit alveolar volume; $\mathrm{PaO}_{2}$-arterial oxygen tension; $\overline{\mathrm{PA}}-\mathrm{aO}_{2}$-alveolar-arterial oxygen tension gradient. ${ }^{*} \mathrm{p}<0.001 ;{ }^{* *} \mathrm{p}<0.01 ;{ }^{* * *} \mathrm{p}<$ 0.05 . 

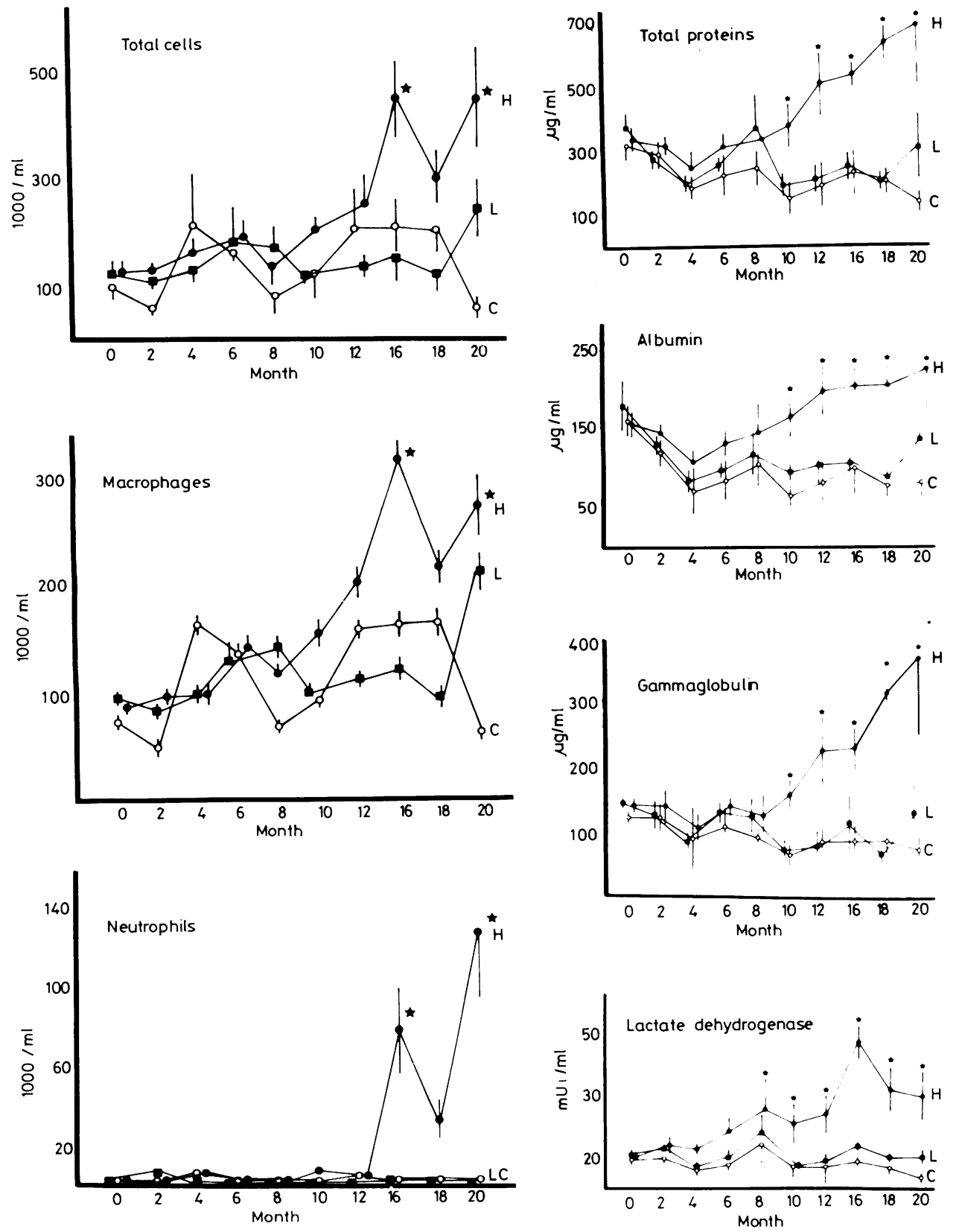

Fig 2 Data on bronchoalveolar lavage fuid. Left-hand panels: cellularity of fuid (expressed as numbers of cells per ml). Right-hand panels: total protein, albumin, gammaglobulin, and lactate dehydrogenase content of the fuid. Values are means \pm 1 SE. O Controls (C); low-asbestos group $(L) ;-$ high-asbestos group $(H) .{ }^{*} p<0.05 H v C$. 

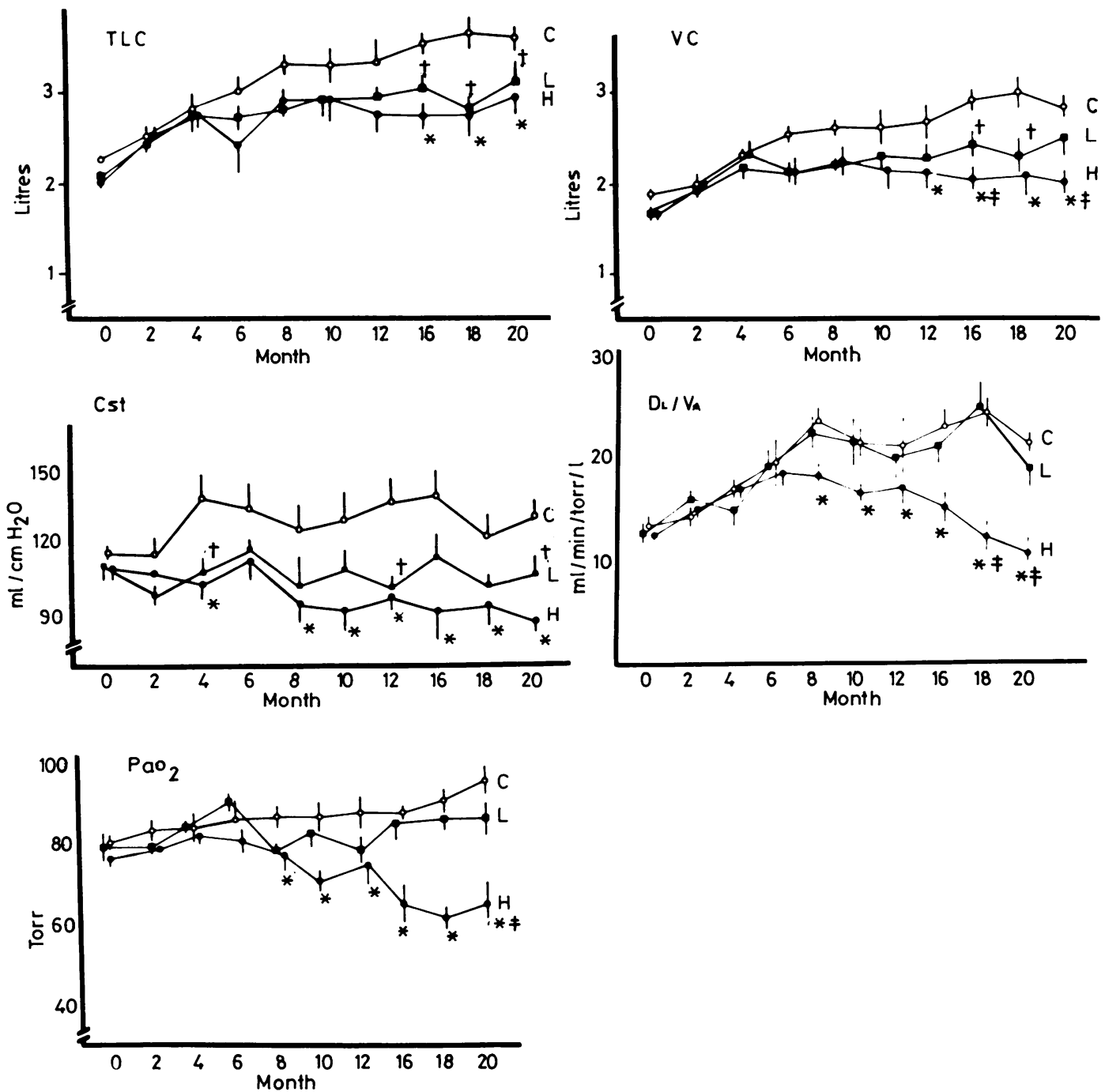

Fig 3 Results of pulmonary function tests in the three groups (symbols and abbreviations as in fig 2). Values are means \pm 1 $S E$. TLC - total lung capacity; VC-vital capacity; $C_{s}$-static expiratory lung compliance; $D L / V A-$ diffusion capacity per unit alveolar volume; $\mathrm{PaO}$-arterial oxygen tension. ${ }^{*} p<0.05 \mathrm{H} v \mathrm{C} ; \dagger+p<0.05 \mathrm{~L} v \mathrm{C} ; \ddagger p<0.05 \mathrm{H} v \mathrm{~L}$.

results of our analysis showing changes in pulmonary function test results in the high-exposure group expressed as percentages of values in controls with similar changes in their bronchoalveolar lavage fluid. Changes over time of $\mathrm{C}_{\mathrm{st}}$, TLC, VC, arterial $\mathrm{PO}_{2}\left(\mathrm{PaO}_{2}\right)$, alveolar-arterial $\mathrm{PO}_{2}$ gradient, and DU/ $\mathrm{VA}_{\mathrm{A}}$ (equivalent to $\mathrm{KcO}$ ) in the high-exposure group were highly correlated with changes in the cellularity of the bronchoalveolar lavage fluid (total bronchoalveolar lavage cells, macrophages, and neutrophils) as well as in the total proteins, albumin, gammaglobulins, lactate dehydrogenase, and $\beta$-glucuronidase of the fluid $(\mathrm{r}>0.8$ for most correlations, $p<0 \cdot 01$ ). Changes over time in FRC, $R V$, and VE did not correlate with changes in the bronchoalveolar lavage fluid $(r<0 \cdot 27, \mathrm{p}>0.05)$.

\section{Discussion}

In the sheep model of asbestosis the initial histopathological lung injury was characterised by a mac- 
rophagic peribronchiolar alveolitis accompanied by leakage of cytoplasmic enzyme and serum proteins in the bronchoalveolar milieu. This early lesion altered lung compliance, vital capacity, and gas exchange values. Without further asbestos exposure thereafter, the alveolitis was reflected in the following months in the cellularity of the bronchoalveolar lavage fluid as macrophages and neutrophils increased gradually and histologically the disease progressed to a fibrosing peribronchiolar alveolitis. Progression of the disease process caused further deterioration of performance in pulmonary function tests, which correlated significantly with bronchoalveolar lavage indices of activity of the alveolitis.

In other interstitial lung diseases it has been well documented that activity of the disease process as judged by histopathological criteria can be accurately evaluated by analysis of the cellularity of the bronchoalveolar lavage fluid, ${ }^{26}$ but pulmonary function tests are considered to have only fair sensitivity and poor specificity for the alveolitis. ${ }^{17-1122}$ While in treatable alveolitis there are sufficient supportive data in the literature to justify repeated assessment of the disease activity with bronchoalveolar lavage fluid analysis, ${ }^{623}$ in the pneumoconioses the clinician has little justification for such procedures in the repeated assessment of activity and progression of the disease. He must rely on less invasive procedures such as chest radiographs and pulmonary function tests.

The rate of progression of asbestosis has been generally assessed by radiological and functional means. In epidemiological surveys of asbestos workers and in serial evaluations of patients with the disease, it has been well established that radiological progression of the disease is accompanied by deterioration in lung compliance, ${ }^{24}$ forced vital capacity, ${ }^{24-29}$ total lung capacity, ${ }^{25}{ }^{27}$ and gas exchange parameters, ${ }^{26}{ }^{30-33}$ but these changes have not been correlated serially with criteria of activity of the disease derived from histopathical examination or bronchoalveolar lavage fluid analysis. Only the study of Gaensler et $\mathbf{l}^{34}$ provides some support for the validity of radiological assessment and pulmonary function tests as means of evaluating the severity of the disease. In their study of 31 asbestos workers who had lung biopsy for diagnostic purposes they found histopathological lesions similar to those observed in our sheep and noted very good agreement between the degree of functional impairment estimated from histological observations and a composite of the severity of physiological disturbances.

The present study in the sheep model of asbestosis clearly establishes that the parameters of deterioration derived from pulmonary function tests are associated with histopathological changes and alterations in the bronchoalveolar lavage fluid which characterise the evolution of the disease process from an initial macrophagic peribronchiolar alveolitis to the late neutrophilic fibrosing peribronchiolar alveolitis. This progression is quite compatible with previous reports on the human disease. ${ }^{34} 35$ Our serial data in the sheep model of asbestosis shows that simple pulmonary function tests such as vital capacity, diffusion capacity, and arterial $\mathrm{PO}_{2}$ measurements correlate well with bronchoalveolar lavage fluid changes in the course of the disease and can be used to assess progression of the disease process.

This work was supported by the Institut de Recherche et Développement de l'Amiante, the Conseil de la Recherche Médicale du Canada, and the Institut de Recherche en Santé et Sécurité au Travail du Québec and by scholarships from the Canadian Life Insurance Association (RB) and the Conseil de la Recherche en Santé du Québec (MRP).

\section{References}

${ }^{1}$ Crystal RG, Gadek JE, Ferrans VJ, Fulmer JD, Line BR, Hunninghake GW. Interstitial lung disease: current concepts of pathogenesis, staging and therapy. Am J Med 1981;70:542-68.

${ }^{2}$ Haslam PL, Turton CWG, Heard B, et al. Bronchoalveolar lavage in pulmonary fibrosis: comparison of cells obtained with lung biopsy and clinical features. Thorax 1980;35:9-18.

${ }^{3}$ Crystal RG, Fulmer JD, Roberts WC, Moss ML, Line BR, Reynolds HY. Idiopathic pulmonary fibrosis. Ann Intern Med 1976;85:769-88.

${ }^{4}$ Gee JBL, Fick RB. Bronchoalveolar lavage. Thorax 1980;35:1-8.

${ }^{5}$ Haslam PL, Turton CWG, Lukoszek A, et al. Bronchoalveolar lavage fluid cell counts in cryptogenic fibrosing alveolitis and their relation to therapy. Thorax 1980;35:328-39.

${ }^{6}$ Hunninghake GW, Kawanami O, Ferrans VJ, Young RC, Roberts WC, Crystal RG. Characterisation of the inflammatory and immune effector cells in the lung parenchyma of patients with interstitial lung disease. Am Rev Respir Dis 1981;123:407-12.

${ }^{7}$ Boushy SF, North LB. Pulmonary function in infiltrative lung disease. Chest 1973;63:448-53.

${ }^{8}$ Keogh BA, Crystal RG. Pulmonary function testing in interstitial pulmonary disease. Chest 1980;78:856-65.

${ }^{9}$ Line BR, Hunninghake GW, Keogh BA, Jones AE, Johnston GS, Crystal RG. Gallium-67 scanning to stage the alveolitis of sarcoidosis: correlation with clinical studies, pulmonary function studies and bronchoalveolar lavage. Am Rev Respir Dis 1981;123:440-6. 
${ }^{10}$ Lourenco RV, Turino GM, Davidson LAG, Fishman AP. The regulation of ventilation in diffuse pulmonary fibrosis. Am J Med 1965;38:199-216.

${ }^{11}$ Lyons HA. Pulmonary compliance in granulomatous disease of the lung. Am J Med 1958;25:23-30.

${ }^{12}$ Bégin $\mathbf{R}$, Rola-Pleszczynski $\mathbf{M}$, Sirois $\mathbf{P}$, Massé $\mathrm{S}$, Nadeau D, Bureau MA. Sequential analysis of the bronchoalveolar milieu in conscious sheep. J Appl Physiol 1981;50:665-71.

${ }^{13}$ Bégin R, Rola-Pleszczynski M, Sirois P, et al. Early lung events following low-dose asbestos exposure. Environ Res 1981;26:535-50.

${ }^{14}$ Timbrell V, Gibson JC, Webster I. UICC reference samples of asbestos. Int J Cancer 1978;3:406-8.

15 Silverton RE. Gross fixation methods used in the study of pulmonary emphysema. Thorax 1965;20:289-97.

${ }^{16}$ Marshall R. A rebreathing method for carbon monoxide diffusing capacity. Am Rev Respir Dis 1977;115:537-9.

${ }^{17}$ Rola-Pleszczynski M, Sirois P, Bégin R. Cellular and humoral components of bronchoalveolar lavage in the sheep. Lung 1981;159:91-9.

${ }^{18}$ Rola-Pleszczynski M, Massé S, Sirois P, Lemaire I, Bégin R. Early effects of low-doses exposure to asbestos on local cellular immune responses in the lung. $J$ Immunol 1981;127:2535-8.

19 Pesce MA, Strande CS. A new micromethod for determination of protein in cerebrospinal fluid and urine. Clin Chem 1974;19:1265-7.

${ }^{20}$ Reynolds HY, Newball HH. Analysis of proteins and respiratory cells obtained from human lungs by bronchial lavage. Lab Clin Med 1974;84:559-73.

${ }^{21}$ Snedecor GW, Cochran WC. Statistical methods. Iowa: Iowa State University Press, 1967.

${ }^{22}$ Fulmer JD, Roberts WC, von Gal ER, Crystal RG. Morphologic-physiologic correlates of the severity of fibrosis in idiopathic pulmonary fibrosis. $J$ Clin Invest 1979;63:665-7.

${ }^{23}$ Rudd RM, Haslam PL, Turner-Warwick M. Cryptogenic fibrosing alveolitis. Relationships of pulmonary physiology and bronchoalveolar lavage to response to treatment and prognosis. Am Rev Respir Dis 1981;124:1-8.

${ }^{24}$ Arzt GH, Pirtkien R, Rosenthai $H$. Review of lung function data in 195 patients with asbestosis of the lung.
Int Arch Occup Environ Health 1980;45:63-79.

${ }^{25}$ Bader ME, Bader RA, Turstein AS, Selikoff IJ. Pulmonary function in asbestosis: serial tests in a long-term prospective study. Ann NY Acad Sci 1965;132:391405.

${ }^{26}$ Becklake MR, Fournier-Massey G, McDonald JC, Siemiatycky J, Rossiter CE. Lung function in relation to chest roentgenographic changes in Quebec asbestos workers. Bull Eur Physiopath Resp 1970;6:637-59.

${ }^{27}$ Becklake MR. Asbestos-related diseases of the lung and other organs: their epidemiology and implications for clinical practice. Am Rev Respir Dis 1976;114:187227.

${ }^{28}$ Weill H, Diem JE, Jones RN, Gilson JC, Glindmeyer H. Relationships between radiographic progression, lung function decline and asbestos exposure level. Thorax 1979;34:422-3.

${ }^{29}$ Zitting A, Huuskonen MS, Alanko K, Mattsson. Radiographic and physiological findings in patients with asbestosis. Scand J Work Environ Health 1978;4:275-83.

${ }^{30}$ Murphy RLH, Ferris BG, Burgess WA, Worcester J, Gaensler EA. Effects of low concentrations of asbestos. Clinical, environmental, radiological and epidemiological observations in shipyard pipe coverers and controls. $N$ Engl J Med 1971;285:1271-8.

${ }^{31}$ Murphy RLH, Gaensler EA, Redding RA, et al. Low exposure to asbestos. Gas exchange in ship pipe coverers and controls. Arch Environ Health 1972;25:253-64.

${ }^{32}$ Britton MG, Hughes DTD, Wever AMJ. Serial pulmonary function tests in patients with asbestosis. Thorax 1977;32:45-52.

${ }^{33}$ Murphy RLH, Gaensler EA, Ferris BG, Fitzgerald M, Solliday N, Morrisey W. Diagnosis of "asbestosis." Observations from a longitudinal survey of shipyard pipe coverers. Am J Med 1978;65:488-98.

${ }^{34}$ Gaensler EA, Carrington CB, Coutu RE, Tomasian A, Hoffman L, Smith AA. Pathological, physiological and radiological correlations in the pneumoconioses. Ann NY Acad Sci 1972;200:575-607.

${ }^{35}$ Bignon J, Atassi K, Jaurand MC, et al. Etude cytologique et biochimique du liquide du lavage bronchoalvéolaire (LBA) dans la fibrose pulmonaire idiopathique et l'asbestose. Rev Franc Mal Resp 1978;6:353-8. 